\title{
SUBJECTIVE NORM OF INTEREST TO USE IN ONLINE SHOPPING
}

\author{
Rini Larasati Irawan*1, Ratih Hurriyati ${ }^{2}$, Mohamad Reza Nurpratama ${ }^{3}$ \\ Universitas Pendidikan Indonesia*12, Universitas Kristen Maranatha ${ }^{3}$ \\ ririn@upi.edu*1, rhurriyati@upi.edu² ${ }^{2}$ mochamadrezan@yahoo.com ${ }^{3}$
}

\begin{abstract}
In this generation, shopping online is not considered a taboo thing anymore. This matter is supported by its various applications that are already familiar to people all over the world. Jakarta is among one of all Indonesian capital cities, where shopping online has made it easier for people to shop and to erase gaps while shopping, saves more time, and it's other advantages. The urge and influence of people around us can be one of the main reasons that might affect it. Subjective norm and interest to use are the two variables used in this research. The data were collected by spreading questionnaires through google forms, the amount of collected respondent are 65 respondent who came from Jakarta. The result of the research used the AMOS program. And the hypothesis test result shows that all probabilities, whether it's the subjective norm or the interest to use, are significant.
\end{abstract}

Keywords: Online Shopping, Interest to Use, Subjective Norm

\section{INTRODUCTION}

Online shopping today is not a strange thing anymore, where many people have become online customers. This is illustrated by the existing online market in Indonesia. Various marketplaces are competing with more sophisticated photo-features they have so that more customers come to their marketplace. So that customers are interested in being interested in the market they have. Purchase control and subjective norms are closely related. This can be found in an article made by Fagih \& Jaradat (2015), which found that norms influence the intention to Use. But Joo (2015) produces results that refuse to state that not being as subjective as the intention to use has no significant relationship.

The theory of reasoned is base on the proposition that individual behavior is determined by Behavioral intention. Behavioral intention is a function of two factors attitude toward the behavior and subjective norm.

Norms that discuss individual beliefs about how subjective criteria will be seen by certain references. Previous studies regarding subjective norms have shown that attitudes are significantly related to subject norms. Chang (1998), Shimp, \& Kavas (1984) have found that there is a significant result that there is a relationship between subjective norms and intention to buy.

The intention to use one of the basics of TAM. Where in studies also studies such as research conducted by Gibreel et al. (2018) have divided the intention to want to use that halved. Where the intention to use is included in the analogs used by most researchers, apart from developing, in previous studies, researchers found that the perceived benefits had a significant effect on the intention to use.

A person will have a desire to do something when there is an influence from an object or behavior that is influenced by the people around him. This can happen when someone believes that the environment or the people around him support what that person will do. Interest in using something is a person's desire to do certain things that they think are right. Intention to use is an attitude that someone tends to want to use in technology, in this case, online shopping (Davis et al., 1989).

The type of data source in this study is primary data, where the data is taken from respondents, which is done by distributing questionnaires. In the research, 65 respondents came from Jakarta residents, who filled out a questionnaire. The data analysis 
method used in this study was to determine the research data.

In subjective norms and the intention to use, these two variables will be tested. In this study, there are two hypotheses:

$\mathrm{H} 1$ : There is an effect of subjective norms on the intention to use online shopping.

$\mathrm{H} 2$ : Whether or not there is an element of a subjective norm in online shopping.

\section{METHODS}

The population in the research was taken from a citizen of Jakarta. The respondent of the research is the ones who is familiar with online shopping with total of 65 respondents people as saplings/ the technique used in the research is the sampling probability technique (Sekaran). This could be a match with other samplings taken from a citizen of Jakarta.

\section{RESULTS AND DISCUSSION}

Table 1. Regression Weight Table

\begin{tabular}{|c|c|c|c|c|c|c|c|}
\hline & & & Estimate & S.E. & C.R. & $\bar{P}$ & Label \\
\hline Interest_to_use & $<--$ & Subjective_Norm & ,961 & 246 & 3,898 & $\star \star \star \star$ & \\
\hline SN1 & $<--$ & Subjective_Norm & 1,000 & & & & \\
\hline SN2 & $<---$ & Subjective_Norm & 1,132 & 264 & 4,292 & *** & \\
\hline SN3 & $<--$ & Subjective_Norm & 1,262 & 281 & 4,492 & $\star * *$ & \\
\hline SN4 & $<--$ & Subjective_Norm & 1,079 & ,272 & 3,963 & $* * *$ & \\
\hline ITU4 & $<--$ & Interest to use & 1,000 & & & & \\
\hline ITU3 & $<--$ & Interest to use & 987 & ,118 & 8,334 & $* \star *$ & \\
\hline ITU2 & $<---$ & Interest to use & .995 & 116 & 8,561 & $\star \star \star *$ & \\
\hline ITU1 & $<---$ & Interest to use & 1,041 & 143 & 7,270 & $\star * *$ & \\
\hline
\end{tabular}

Source: Data that has been processed by the author (2020)

From the data above, output regression weight, when value $P$ (probability) didn't look to significant (above 0,05) then the indicator has been erased it can be seen on the table above that the whole value of $\mathrm{P}$ is above 0,05 , although subjective norm and intention to use is significant. 
Table 2. The goodness of Fit Test

\begin{tabular}{llll}
\hline Goodness of Fit & Cut off value & Result & Conclusion \\
\hline CMIN/DF & $\leq 2,00$ & 2,521 & Bad Fit \\
GFI & $\geq 0,90$ & 0,833 & Bad Fit \\
AGFI & $\geq 0,90$ & 0,684 & Bad Fit \\
CFI & $\geq 0,90$ & 0,910 & Fit \\
TLI & $\geq 0,90$ & 0,868 & Bad Fit \\
NFI & $\geq 0,90$ & 0,863 & Bad Fit \\
IFI & $\geq 0,90$ & 0,913 & Fit \\
RMSEA & $\leq 0,08$ & 0,002 & Bad Fit \\
RMR & $\leq 0,05$ & 0,440 & Bad Fit \\
\hline
\end{tabular}

Source: Data that has been processed by the author (2020)

From the above output, can be seen in table 2 that there are 2 criteria that has already fill fit therefore can be concluded that not in that mode is fit. Overall, the goodness of fit can't be valued at at least two criteria.

\section{CONCLUSION}

The result of subjective norms on an intention to use still lacks in terms of the number of respondents, although when viewed in terms of probability in research conducted by researchers, the probability between subjective norms and intention to use is good. For further research, is is expected to increase the number of respondents in the study.

\section{REFERENCES}

Ajzen, I. (1985). From Intention to Actions: A Theory of Planned Behavior', In J. Kuhland and J. Beckman (eds.). Action-control:
From Cognitions to Behavior (Springer, Heidelberg), pp. 11-39.

Chan, S.C., Lu, M.T. (2004) Understanding Internet Banking Adoption and Use behavior: A Hong Kong perspective. Journal of Global Information Management, 12,3, 2004, 12-43.

Davis et al. (1989). User Acceptance of Computer Technology: A Comparison of Two Theoritical Models. Management Science Vol 35(8), p982-1003.

Fagih \& Jaradat. (2014) Assessing the moderating effect of gender differences and individualismcollectivism at individual-level on the adoption of mobile commerce technology: TAM3 perspective', Journal of Retailing and Consumer Service. 22.

Sekaran, Uma. (2011). Research Methods For Business (Metode 
Almana : Jurnal Manajemen dan Bisnis Vol. 4 No. 3/ December 2020

ISSN 2579-4892 print/ ISSN 2655-8327 online

Penelitian Untuk Bisnis). Jakarta: Salemba Empat.

Shimp, T. A. \& Kavas. (1984). The

Theory of Reasoned Action

Applied to Coupon Usage',
Journal of Consumer Research 11, 795-809. 